\title{
Cardiovagalis és szimpatikus artériás baroreflex szabályozásának vizsgálata szívelégtelenségben
}

\author{
Urbancsek Réka dr. ${ }^{1}$ - Forgács Ildikó Noémi ${ }^{1}$ \\ Papp Tímea Bianka dr. ${ }^{1}$ - Boczán Judit dr. ${ }^{2}$ - Barta Judit dr. ${ }^{1}$ \\ Édes István dr. ${ }^{1}$. Csanádi Zoltán dr. ${ }^{1}$ - Rudas László dr. ${ }^{3}$ \\ ${ }^{1}$ Debreceni Egyetem, Általános Orvostudományi Kar, Kardiológiai és Szívsebészeti Klinika, Debrecen \\ ${ }^{2}$ Debreceni Egyetem, Általános Orvostudományi Kar, Neurológiai Klinika, Debrecen \\ ${ }^{3}$ Szegedi Tudományegyetem, Általános Orvostudományi Kar, Aneszteziológiai és Intenzív Terápiás Intézet, \\ Szeged
}

\begin{abstract}
Bevezetés: Az artériás baroreflex-érzékenységi (BRS-) indexek egységnyi nyomásváltozásra adott élettani válaszokat írnak le. Az RR-intervallum gyors válaszait a cardiovagalis BRS-indexekkel, a vasomotorválaszokat az izom szimpatikus idegi aktivitás (MSNA) válaszain alapuló szimpatikus-BRS-indexekkel jellemezzük. Szívelégtelenségben kórosan csökkent értékeik kedvezőtlen kimenetelt jeleznek.

Betegek és módszerek: A BRS-indexek meghatározhatóságát 52, szívelégtelenségben szenvedő betegben (kor: $59 \pm 10$ év; EF: $37 \pm 11 \%$ ) és 11 , kor szerint illesztett egészséges önkéntesben vizsgáltuk. EKG- és vérnyomásfelvételekből három cardiovagalis BRS-indexet számítottunk; a növekvő, illetve csökkenő spontán szekvenciák módszerén alapuló up-BRS-t és down-BRS-t, továbbá az alacsony frekvenciatartomány-beli 'cross-spectralis 'indexet, az LF-alfát. Egy perifériás ideg (nervus peroneus) perkután punkciójával detektáltuk az MSNA szimpatikus csúcs incidenciáját (csúcs/100 szívciklus), s ezt korreláltattuk a diastolés nyomás $3 \mathrm{Hgmm}$ sávokba rendezett értékeivel. Így nyertük a szimpatikus BRS jellemzőit, a $B R S_{\text {SY-incidencia }}$-értékeket.

Eredmények: Az up- és down-BRS-szekvenciák csak a betegek 19\%-ában voltak meghatározhatók, az LF-alfa a 69\%-ukban. Azok, akiknél cardiovagalis BRS nem volt meghatározható, szignifikánsan csökkent RR-intervallum-ingadozást és magasabb NT-proBNP-értékeket mutattak. A meghatározható cardiovagalis BRS-indexek nem különítették el a betegeket és a kontrollszemélyeket. A BRS ${ }_{\mathrm{SY} \text {-incidencia }}$-érték $58 \%$-ban állt rendelkezésre, s csakúgy, mint maga a „csúcs” incidencia, jól elkülönítette a betegeket és az önkénteseket. A hiányzó baroreflexérték a magas „csúcs” incidenciával állt összefüggésben.

Következtetés: A cardiovagalis BRS-értékek csak korlátozottan alkalmasak egészséges önkéntesek és szívelégtelen betegek elkülönítésére, a meghatározhatatlan értékek súlyosabb betegségre utalnak. A BRS ${ }_{\text {SY-incidencia }}$ elkülöníti az egészséges és a beteg csoportokat; a hiányzó érték a fokozott szimpatikus aktivitással áll összefüggésben.

Orv Hetil. 2021; 162(3): 91-98.
\end{abstract}

Kulcsszavak: szívelégtelenség, spontán szekvenciális BRS, spektrális BRS, MSNA, szimpatikus BRS

\section{Cardiovagal and sympathetic baroreflex regulation in heart failure}

Introduction: Arterial baroreflex sensitivity (BRS) is characterized by the magnitude of physiological responses to arterial pressure changes. Rapid RR interval responses are quantified by cardiovagal BRS parameters, sympathetic responses could be assessed by changes in muscle sympathetic nerve activity (MSNA). Abnormal indices in heart failure are associated with poor outcome.

Patients and methods: 52, heart failure patients (age $59 \pm 10$ years, EF $37 \pm 11 \%$ ), and 11 , age-matched healthy volunteers were studied. From ECG and arterial pressure recordings $u p-B R S$ and $d o w n-B R S$ values were determined using the method of spontaneous sequences. The low frequency cross-spectral gain, the $L F$ alpha was also determined. Percutaneous puncture of the peroneal nerves allowed determination of MSNA burst incidence (burst/100 cycles), which was correlated to corresponding diastolic pressure bins of $3 \mathrm{mmHg}$, yielding a sympathetic BRS, the $B R S_{\text {SY-incidence }}$. 
Results: Up- and down-BRS could be calculated in 19\% of the patients, LF alpha was determined in 69\%. Those with missing cardiovagal BRS values showed diminished RR interval variation, and higher levels of NT-proBNP. The measurable cardiovagal BRS indices did not separate patients and healthy volunteers. BRS $_{\text {SY-incidence }}$ could be determined in $58 \%$ of the patients. The sympathetic gain as well as the burst incidence differed significantly between patients and healthy volunteers. Missing $\mathrm{BRS}_{\mathrm{SY} \text {-incidence }}$ was associated with higher burst incidence.

Conclusion: Cardiovagal BRS indices have limited value in differentiating healthy and heart failure subjects. Incalculable values among patients indicate more severe disease state. $\mathrm{BRS}_{\mathrm{SY} \text {-incidence }}$ does separate healthy and diseased population, the missing $\mathrm{BRS}_{\mathrm{SY} \text {-incidence }}$ values are related to increased sympathetic activity.

Keywords: heart failure, spontaneous sequence BRS, cross-spectral BRS, MSNA, sympathetic BRS

Urbancsek R, Forgács IN, Papp TB, Boczán J, Barta J, Édes I, Csanádi Z, Rudas L. [Cardiovagal and sympathetic baroreflex regulation in heart failure]. Orv Hetil. 2021; 162(3): 91-98.

(Beérkezett: 2020. június 23.; elfogadva: 2020. július 31.)

\section{Rövidítések}

$\mathrm{BRS}=$ (baroreflex sensitivity) baroreflex-érzékenység; $\mathrm{BRS}_{\mathrm{SY}}$ incidencia $=$ „csúcs” incidencián alapuló szimpatikus BRS; COPD = chronic obstructive pulmonary disease) krónikus obstruktív tüdőbetegség; down-BRS = csökkenő szekvenciák BRS-értéke; $\mathrm{EF}=$ ejekciós frakció; $\mathrm{EKG}=$ elektrokardiográfia; $\mathrm{ES}=$ extrasystole; $\mathrm{LF}$-alfa $=$ az alacsony frekvenciasávú RR-intervallum- és a systolés nyomás teljesítménysűrúségek hányadosának négyzetgyöke; MSNA = (muscle sympathetic nerve activity) izom szimpatikus idegi aktivitás; NKFIH = Nemzeti Kutatási Fejlesztési és Innovációs Hivatal; NT-proBNP $=\mathrm{N}$-terminális proB-típusú natriureticus peptid; NYHA = (New York Heart Association) New York-i Szívbetegséggel Foglalkozó Társaság; RMSSD = egymást követő RR-ciklushossz-különbségek négyzetei átlagának négyzetgyöke; RR-átlag = az EKG-regisztrátum RR-intervallum-hosszúságainak átlaga; RRSD = RR-intervallumok standard deviációja; up-BRS = növekvő szekvenciák BRS-értéke

\section{Az artériás baroreflex fogalma, jelentösége}

Az artériás baroreflex-érzékenység (baroreflex sensitivity = BRS) az autonóm idegrendszer által közvetített idegaktivitási, illetve célszervmúködési paraméterben bekövetkező változásokat írja le a baroreflex-stimulus egységnyi változásának hatására. A stimulus a feszülés-, illetve átmérőváltozás a „baroreceptív” érszakaszokon, ezt a gyakorlatban az artériás nyomásváltozás helyettesíti. Az efferens válaszokat a paraszimpatikus és szimpatikus ágak közvetítik. A sinuscsomó felé haladó paraszimpatikus válaszok gyorsak, azonnaliak. A szimpatikus válaszok lassúbbak, $\mathrm{s}$ a válasz mértéke is kisebb. A pulzus gyors ingadozásai paraszimpatikus hatásokat tükröznek, ezek „árnyékában” a szimpatikus hatások nehezen értelmezhetók.

\section{A cardiovagalis BRS}

A vérnyomás és az RR-intervallum-változás közti összefüggés egy szigmoid görbével írható le, melynek több- nyire csak a középső, lineáris szakaszát tanulmányozzuk. A gyógyszeres teszteket vasopressorbolusszal vagy szekvenciális vasopressor-vasodilatator boluszokkal végezzük, s az emelkedő, illetve csökkenő szakaszokon határozzuk meg a systolés értékek és az azokat követő RR-intervallumok közti lineáris regresszió meredekségét [1]. Nyugalomban a természetes vérnyomáshullámzások olyan RR-intervallum-változásokat indukálnak, melyek alapján rövid, „spontán baroreflex-szekvenciák” válnak meghatározhatóvá [2-5]. A szekvenciát legkevesebb 3 emelkedő vagy csökkenő systolésnyomás-érték és a hozzájuk tartozó nyúló vagy rövidülő RR-intervallumok képezik. Feltétel a lépésenként legalább 1 Hgmm nyomásés 5 ms RR-intervallum-változás, erős $(\geq 0,8)$ korrelációs koefficiens mellett [5]. Legalább 5-5 növekvő, illetve csökkenő szekvencia átlagát tekintjük spontán BRS-értékeknek, ezek a növekvő (up-BRS), illetve csökkenő (down-BRS) indexek.

Egy további spontán módszer spektrális analízisen alapul. A vérnyomás és a pulzus hullámzásait matematikailag összetevő hullámokra bontjuk, s a megfelelő frekvenciákhoz tartozó komponenshullámokat a teljesítményükkel jellemezzük. Az így képzett teljesítménysưrúségi spektrumot egy $0,05-0,15 \mathrm{~Hz}$ közti alacsony és egy $0,15 \mathrm{~Hz}$ feletti magas frekvenciasávra osztjuk $[3,4]$. A magasabb sávban a légzési változások jelennek meg. A vérnyomásnál az alacsony sávban szimpatikus hatások által generált hullámok találhatók, s ezek artériás baroreflex-múködés révén (vagalis efferens közvetítéssel) megjelennek a pulzusban is. Ebben a sávban az RR-intervallumok és a systolés nyomás teljesítményei közt spektrális BRS-t határozunk meg, melyet itt az RR-intervallum- és a systolés nyomás teljesítménysưrúségek hányadosának négyzetgyökeként definiálunk (LF-alfaindex) $[3,4]$. Elvárt a teljesítménysứrúségek között a $\geq 0,5$ koherencia $[3,4]$. A különböző módszerekkel meghatározott cardiovagalis BRS-ek kapcsolatban állnak, de számértékeik nem helyettesíthetók be egymással [5]. 


\section{A szimpatikus baroreflex-érzékenység}

Az artériás baroreceptorok feszülésváltozására adott legfontosabb válasz a vérnyomás visszaállítása a kiindulási helyzetbe. Ennek tanulmányozását teszi lehetővé a vasomotoros szimpatikus idegek aktivitását közvetlenül méró mikroneurográfia. A vizsgálat során egy perifériás ideget - többnyire a nervus peroneust - egy mikrotúvel megszúrjuk, s megfelelő pozicionálással, standardizált jelfeldolgozást követően, a szimpatikus rostok integrált multiunit-aktivitási jeleit regisztráljuk. Ez az izom szimpatikus idegi aktivitás (muscle sympathetic nerve activity = MSNA). Az aktivitási csúcs („burst”) jellegzetes pozitív irányú kiugrások formájában jelenik meg a felvételen (1. ábra). A csúcsok jelentkezése nagyon szorosan kapcsolódik az artériás nyomáshullámokhoz, s így a szívciklusokhoz, ezért az MSNA-frekvencia (csúcs/perc) mellett megadjuk a „burst” incidencia (csúcs/100 szívciklus) értékeit is. A csúcsok megjelenése a legszorosabb kapcsolatot a diastolés nyomással mutatja [6].

A nyomás-MSNA összefüggés (szimpatikus BRS) meghatározását nehezíti, hogy egészséges alanyokban nem minden szívciklushoz tárul szimpatikus csúcs. Ezt a problémát úgy kezeljük, hogy a felvételen regisztrált diastolés nyomásértékeket $3 \mathrm{Hgmm}$-es sávokba rendezzük, s ezekhez rendeljük hozzá megfelelő válaszidejú késleltetéssel a csúcsokat. A szimpatikus BRS értékelhető úgy, hogy a sávokhoz tartozó csúcsok normalizált amplitúdóját vagy görbe alatti területét átlagoljuk, $s$ így határozzuk meg a diastolés nyomás-MSNA összefügggést $[1,7]$. Egy másik megközelítésben azt határozzuk meg, hogy az egyes sávokba tartozó ciklusok hány százalékában jelentkezik szimpatikus csúcs [1, 6-10]. Ezt az „incidencia-BRS"-nek ( $\left.B R S_{\text {SY-incidencia }}\right)$ is nevezett módszert széles körben használják [7, 11-13].

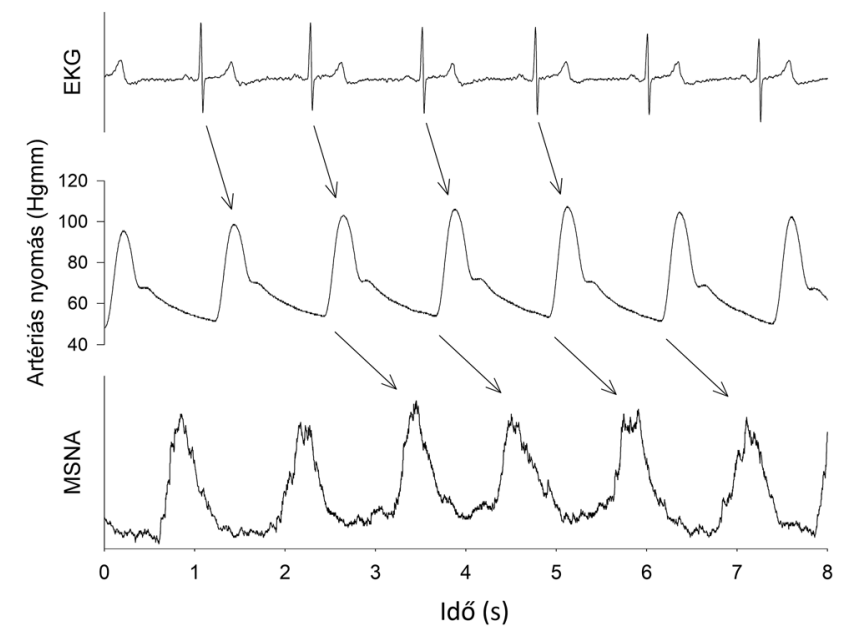

1. ábra

Szívelégtelenségben szenvedő beteg EKG-, vérnyomás- és MSNA-regisztrátuma. Az ábra a szimpatikus csúcsnak az „indító R-hullámhoz" viszonyított késését is illusztrálja

$\mathrm{EKG}=$ elektrokardiográfia $; \mathrm{MSNA}=$ izom szimpatikus idegi aktivitás

\section{Az autonóm keringésreguláció zavara szinelégtelenségben}

A szívelégtelenség napjainkban a világ fejlettebb országaiban a legfontosabb egészségi problémák közé került [14]. Azt, hogy a szívelégtelenség a cardiovagalis BRS csökkenésével jár, rég felismertük [15]. A felismerés akkor került az érdeklődés középpontjába, amikor szívinfarktust követően [16], majd szívelégtelenségben [17] igazolták, hogy a fenilefrinboluson alapuló BRS kóros értéke a mortalitás, illetve a kedvezőtlen kimenetel prediktora. Utóbb tisztázódott, hogy a spontán spektrális BRS hasonló prediktív értékkel bír [18, 19].

A kóros szimpatikusaktivitás-növekedés a szívelégtelenség fontos patomechanizmusa, az emelkedett keringő katecholaminszintek összefüggenek a kedvezőtlen kimenettel [20]. Fokozott az MSNA-csúcsfrekvencia és -incidencia [21, 22], s ez szintén a mortalitás előjele [23]. Az MSNA kórosan csökkent baroreflex-modulációja jól dokumentált $[24,25]$, a kimenetelre gyakorolt hatását azonban közvetlenül még nem vizsgálták.

\section{Célkitüzés}

Vizsgálatunkban szívelégtelenségben szenvedő, kardiológiai gondozás alatt álló, optimális gyógyszeres kezelésben részesülö betegek cardiovagalis, illetve szimpatikus baroreflex-regulációját kívántuk tanulmányozni spontán baroreflex-technikákkal. Jelen tanulmányunk középpontjában az egyes baroreflexindexek vizsgálhatósága, gyakorlati alkalmazhatósága állt. Meg kívántuk határozni azokat a klinikai paramétereket is, amelyek a meghatározható, illetve a meg nem határozható baroreflex-indexú alcsoportokra jellemzőek.

\section{Betegek és módszerek}

A vizsgálatokat a Debreceni Egyetem Klinikai Központ Regionális és Intézményi Kutatásetikai Bizottsága etikai engedélyének birtokában végeztük. A vizsgálatba 52 stabil, legalább fél éve kardiológiai gondozás alatt álló s ez idő alatt kórházi felvételt nem igénylő, optimális gyógyszeres kezelésben részesülő járó beteget vontunk be, akiknek társbetegségei közt nem szerepelt cukorbetegség, illetve COPD. Jelen tanulmányunkba nem vontunk be pitvarfibrillációban, illetve gyakori extrasystoliában szenvedőket. Összehasonlítás céljából bevontunk a vizsgálatba 11 , életkor szerint egyeztetett egészséges önkéntest is.

A vizsgálatokra a délelőtti órákban kerítettünk sor, a szokásos gyógyszerek bevétele után. A vizsgált személyek nyugalmi fekvő testhelyzetben voltak. Az EKG-t Eagle monitorral (Marquette Electronics, Inc., Milwaukee, WI, USA) követtük, a vérnyomást folyamatosan mértük (Finapres model 2300; Ohmeda, Denver, CO, USA). Az MSNA-jeleket a jobb oldali nervus peroneus felkeresését és mikrotúvel végzett punkcióját követően 
nyertük. A mikroneurográfiás jeleket a Nerve Traffic Analyzer berendezéssel (model 662C-4, Bioengineering, University of Iowa, Iowa City, IA, USA) dolgoztuk fel. Az előerősítés, egyenirányítás, szűrés és jelintegrálás nyomán nyert MSNA-szignált, továbbá a vérnyomás- és EKG-jeleket csatornánként $500 \mathrm{~Hz}$ mintavételezéssel digitalizáltuk (Dataq Instruments, Akron, OH, USA). A jelek offline analíziséhez a WinCPRS szoftvert (Absolute Aliens Ay, Turku, Finnország) használtuk. A program automatikus EKG-R-hullám-detekciót hajt végre, detektálja a systolés és diastolés értékeket, s ugyancsak automatikusan határozza meg az MSNA-csúcsokat. Az utóbbiak az ingerület terjedési idejének megfelelően felnőttekben az indító diastolésnyomás-értékhez köthető R-hullámot követően 1,3 s késéssel várhatók (1. ábra). Az értékelést valamennyi jelnél ellenőriztük, és szükség esetén editáltuk. Meghatároztunk bizonyos jellemzó időtartomány-beli pulzusvariabilitási paramétereket is, mint az RR-átlag, az RR-intervallum standard deviáció (RRSD) és az egymást követő ciklushosszkülönbségek négyzetei átlagának négyzetgyöke (RMSSD) [26].

A cardiovagalis BRS meghatározásához csak 3 percnél hosszabb, összefüggő, extrasystole (ES)-mentes szakaszokat használtunk, ezek hiányában a regisztrátumot ezekből az analízisekből kizártuk [18]. Az ellenőrzött jelek alapján a program a bevezetőben leírt kritériumok szerint meghatározta az up-BRS-, a down-BRS-, az LFalfa-értékeket. Ugyancsak a bevezetőben leírt elvek alapján határoztuk meg a $\mathrm{BRS}_{\mathrm{SY} \text {-incidencia }} \mathrm{t}$; az értékelhető öszszefüggést a 0,4-es korrelációs koefficienshez kötöttük [13].

1. táblázat A cardiovagalis paraméterek a beteg- és az önkéntescsoportban

\begin{tabular}{lccc}
\hline & Betegek & $\begin{array}{c}\text { Egészséges } \\
\text { önkéntesek }\end{array}$ & $\mathrm{p}$ \\
\cline { 2 - 4 } & $\mathrm{n}=52$ & $\mathrm{n}=11$ & \\
\hline RR-átlag (ms) & $955 \pm 199$ & $911 \pm 166$ & $\mathrm{NS}$ \\
\hline RRSD (ms) & $27 \pm 11$ & $34 \pm 19$ & $\mathrm{NS}$ \\
\hline RMSSD (ms) & $17 \pm 8$ & $21 \pm 17$ & $\mathrm{NS}$ \\
\hline Up-BRS (ms/Hgmm) & $7,7 \pm 4$ & $10,4 \pm 5$ & $\mathrm{NS}$ \\
& $(\mathrm{n}=11)$ & $(\mathrm{n}=9)$ & \\
\hline Down-BRS (ms/Hgmm) & $8,1 \pm 4$ & $9,6 \pm 5$ & $\mathrm{NS}$ \\
& $(\mathrm{n}=11)$ & $(\mathrm{n}=9)$ & \\
\hline LF-alfa (ms/Hgmm) & $7,7 \pm 5$ & $10,9 \pm 5$ & NS \\
& $(\mathrm{n}=36)$ & $(\mathrm{n}=10)$ & \\
\hline
\end{tabular}

BRS = baroreflex-érzékenység; down-BRS = csökkenő szekvenciák BRS-értéke; LF-alfa = az RR-intervallum- és a systolés nyomás teljesítménysűrűségek hányadosának négyzetgyöke; NS = nem szignifikáns; RMSSD = egymást követő RR-ciklushossz-különbségek négyzetei átlagának négyzetgyöke; RR-átlag = az EKG-regisztrátum RR-intervallum-hosszúságainak átlaga; RRSD = RR-intervallumok standard deviációja; up-BRS = növekvő szekvenciák BRS-értéke
A statisztikai analíziseket a SigmaStat 2.0 programcsomaggal (Systat Software Inc., San Jose, CA, USA) végeztük. A vizsgált alcsoportokat varianciaanalízissel hasonlítottuk össze, az egyes paraméterek közti összefüggést lineáris regresszióval teszteltük.

\section{Eredmények}

Az 52 beteg ( 44 férfi, 8 nő) és a 11 önkéntes ( 9 férfi, 2 nő) kora nem különbözött ( $59 \pm 10$ vs. $56 \pm 9$ év; p = NS). A betegek testtömegindexe $\left(30 \pm 4 \mathrm{~kg} / \mathrm{m}^{2}\right)$ szignifikánsan nagyobb volt, mint az önkénteseké $(26 \pm 4 \mathrm{~kg} /$ $\left.\mathrm{m}^{2}, \mathrm{p}=0,005\right)$.

Az etiológia 30 esetben ischaemiás szívbetegség, 22 esetben nem ischaemiás cardiomiopathia volt. A betegek ejekciós frakciója (EF) $37 \pm 11 \%$ (tartomány 14-49\%), NT-proBNP-szintjük $1072 \pm 2065 \mathrm{pg} / \mathrm{ml}$ volt. A NYHA I., illetve II. kategóriának 42 beteg klinikai állapota felelt meg, 10 beteg tartozott a NYHA III-IV. csoportba. 49 beteg részesült maximálisan tolerált béta-blokkoló-, 51 pedig ACE-inhibitor- vagy ARB-terápiában.

\section{A cardiovagalis szabályozás paraméterei}

Az RR-intervallumok átlagait, valamint az időtartomány-beli pulzusszám-variabilitási paramétereket az 1 . táblázat mutatja be. A cardiovagalis baroreflexindexek analíziséből 12 beteg felvételét kellett kizárni legalább 180 s-os ES-mentes regisztrátum hiányában, a további betegeknél a vizsgálható szakasz hossza $276 \pm 42$ s volt. A kontrollszemélyek közül l felvételt kellett kizárni túl rövid ES-mentes szakasz miatt. Az LF-alfa-meghatározást további 4 betegben és 1 önkéntesben zárta ki a 0,5 alatti koherenciaérték. Az up-BRS és a down-BRS 11-11 alanynál volt lehetséges, a további esetekben nem állt rendelkezésre a minimálisan elvárt számú szekvencia. A kontrollok közül 1 felvételen nem találtunk up-, illetve down-szekvenciákat (1. táblázat).

2. táblázat | Szimpatikus paraméterek

\begin{tabular}{llll}
\hline & Betegek & $\begin{array}{l}\text { Egészséges } \\
\text { Önkéntesek }\end{array}$ & $\mathrm{p}$ \\
\cline { 2 - 3 } & $\mathrm{n}=52$ & $\mathrm{n}=11$ \\
\hline Csúcsfrekvencia & $47 \pm 16(\mathrm{n}=52)$ & $27 \pm 11(\mathrm{n}=11)$ & $<0,001$ \\
$($ csúcs/perc) & & & \\
\hline
\end{tabular}

Csúcsincidencia $72 \pm 18(\mathrm{n}=52) \quad 40 \pm 14(\mathrm{n}=11)<0,001$
(csúcs/100 ciklus)

BRS $_{\text {SY-incidencia }} \quad-2 \pm 0,9(\mathrm{n}=30) \quad-3,4 \pm 2(\mathrm{n}=9) \quad 0,005$

(csúcs / 100 ciklus /

$\mathrm{Hgmm})$

$\mathrm{BRS}=$ baroreflex-érzékenység; $\mathrm{BRS}_{\mathrm{SY} \text {-incidencia }}=$ csúcsincidencián alapuló szimpatikus BRS 
Az egészséges önkéntesekben az up-BRS és a downBRS között szoros összefüggés mutatkozott, csakúgy, mint az up-BRS és az LF-alfa, valamint a down-BRS és az LF-alfa között $(\mathrm{R}=0,94, \mathrm{R}=0,84, \mathrm{R}=0,87$, $\mathrm{p}<0,001)$. A vizsgált betegek körében az up- és downBRS között szoros $(\mathrm{R}=0,90)$, a down-BRS és az LFalfa között $(\mathrm{R}=0,77 ; \mathrm{p}=0,02)$ kevésbé szoros összefüggés volt kimutatható; az up-BRS és az LF-alfa között az összefüggés nem érte el a szignifikanciaszintet.

\section{Szimpatikus paraméterek}

A betegek és egészséges önkéntesek körében vizsgált szimpatikus paramétereket a 2. táblázat mutatja be.

A BRS $_{\text {SY-incidencia }}$-ról az önkéntesek több mint 80\%ában sikerült adatot nyerni, ezzel szemben a betegeknek csak az 58\%-ában volt meghatározható, a többieknél túl alacsonynak bizonyult a korrelációs koefficiens (2. ábra).

\section{Alcsoportvizsgálatok a BRS-indexek meghatározhatósága szerint}

Azon betegeket, akiknek legalább egy szekvencia-BRSük (up- vagy down-BRS) vagy értékelhető alfa-indexük volt $(\mathrm{n}=39)$, összehasonlítottuk azokkal, akiknél nem lehetett meghatározni ezeket a paramétereket $(\mathrm{n}=13)$. Az adatokat a 3. táblázat mutatja be.

Ugyancsak összehasonlítottuk azokat a betegeket, akiknél számítható volt, illetve nem volt számítható a $\mathrm{BRS}_{\mathrm{SY} \text {-incidencia }}$-érték. Itt azonban mindössze egy paraméterben mutatkozott szignifikáns különbség: az NTproBNP-szint volt magasabb abban a csoportban, ahol BRS-érték nem volt mérhető $(1830 \pm 2948$ vs. $583 \pm$ $1002 \mathrm{pg} / \mathrm{ml} ; \mathrm{p}<0,05)$. Szignifikanciahatáron lévő különbség volt a „burst” incidenciában; $68 \pm 16$ csúcs $/ 100$ ciklus számítható index mellett és $78 \pm 19$ csúcs / 100 ciklus a nélkül $(\mathrm{p}=0,05)$.

A
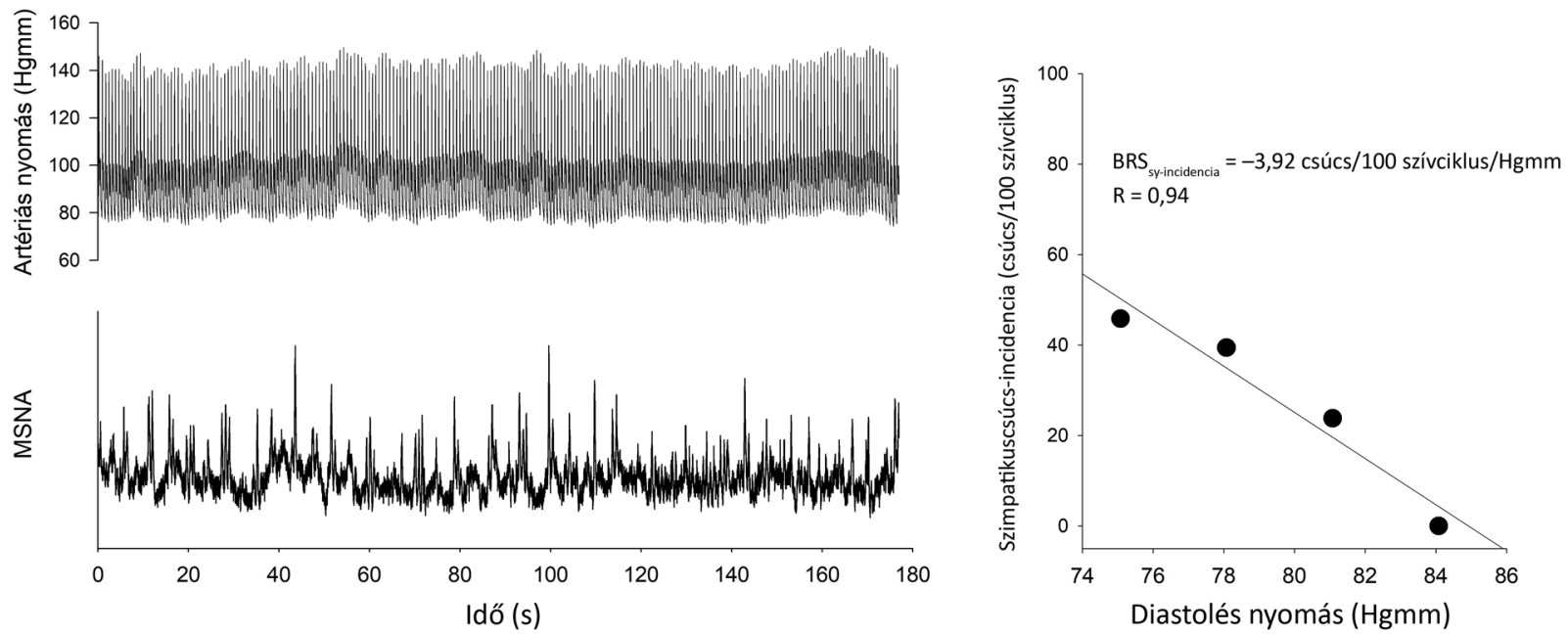

B
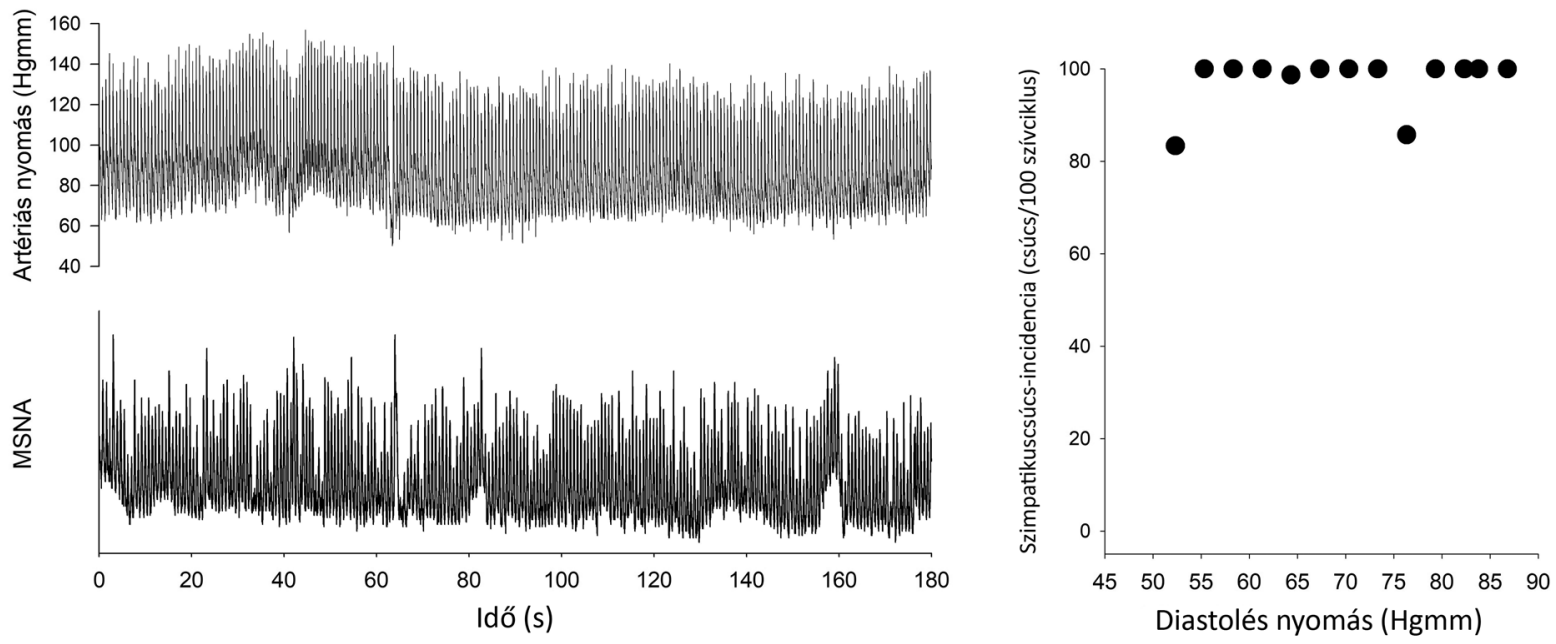

2. ábra

Egészséges önkéntes (felső „A” panelek) és szívelégtelenségben szenvedő alany (alsó „B” panelek) EKG-, vérnyomás- és MSNA-felvételeinek egy-egy szakasza és a felvételek alapján kalkulált diastolés nyomás-szimpatikuscsúcs-incidencia összefüggés. A beteg felvételén $100 \%$-hoz közelít a csúcsincidencia, s nincs a diastolés nyomással korreláció

$\mathrm{EKG}=$ elektrokardiográfia $; \mathrm{MSNA}=$ izom szimpatikus idegi aktivitás 


\section{Megbeszélés}

Hagyományosan a cardiovagalis baroreflexindexek kedvezőtlen prognózishoz való kapcsolódását bizonyos határértékekhez kötjük, jelen vizsgálatunkban azonban a „meghatározható” spontán baroreflexértékek nem különítették el a betegeket az egészséges kontrolloktól. E megfigyelés hátterében két tényező áll. Az egyik ok az életkorból adódik. A cardiovagalis baroreflexindexek az életkor előrehaladtával szívelégtelenség nélküli alanyokban is csökkennek [27], ez a tény nehezítheti az elkülönítést. A másik, fontosabb ok, hogy a baroreflexindex sok betegnél - feltehetóleg a súlyosabb állapotúaknál hiányzott. La Rovere és mtsai 2011 -es közleményükben megállapították, hogy a fenilefrinboluson alapuló meghatározás szívelégtelen betegekben $89 \%$-ban sikeres, ezzel szemben a spektrális BRS-index-meghatározás csak 72\%-ban volt lehetséges [19]. Ez a vizsgálat s egy korábbi közlemény is bizonyította, hogy a spektrális BRS-index meghatározhatatlansága szívelégtelenségben szenvedő betegekben önmagában is kedvezőtlen prognosztikai jel $[18,19]$. Ezekben a tanulmányokban hangsúlyozták, hogy a sikertelen BRS-meghatározás egyik faktora a gyakori extrasystolia, mely önmagában is összefüggésbe hozható a kedvezőtlen kimenetellel [19]. Saját vizsgálatunkban a szekvenciákon alapuló BRS-értékek az egészséges önkéntesek több mint 80\%-ában, a betegeknek csak a 20\%-ában voltak meghatározhatók. A mi betege-

3. táblázat |A betegek jellemzői a cardiovagalis BRS meghatározhatósága szerinti bontásban

\begin{tabular}{lccc}
\hline & $\begin{array}{c}\text { Cardiovagalis } \\
\text { BRS-értékkel }\end{array}$ & $\begin{array}{c}\text { Cardiovagalis } \\
\text { BRS-érték nélkül }\end{array}$ & $\mathrm{p}$ \\
\cline { 2 - 4 } & $\mathrm{n}=39$ & $\mathrm{n}=13$ & \\
\hline Kor (év) & $58 \pm 10$ & $63 \pm 9$ & $\mathrm{NS}$ \\
EF (\%) & $39 \pm 9$ & $33 \pm 12$ & $\mathrm{NS}$ \\
BMI & $30 \pm 3$ & $31 \pm 5$ & $\mathrm{NS}$ \\
RR-átlag (ms) & $997 \pm 202$ & $862 \pm 149$ & 0,05 \\
RRSD (ms) & $29 \pm 11$ & $18 \pm 6$ & $<0,01$ \\
RMSSD (ms) & $19 \pm 8$ & $12 \pm 5$ & 0,03 \\
NT-proBNP & $571 \pm 656$ & $2342 \pm 3518$ & $<0,01$ \\
$\begin{array}{l}\text { Szimpatikuscsúcs-aktivi- } \\
\text { tás (csúcs/perc) }\end{array}$ & $43 \pm 12$ & $57 \pm 20$ & $<0,05$ \\
$\begin{array}{l}\text { Szimpatikuscsúcs-inci- } \\
\text { dencia (csúcs/100 }\end{array}$ & $70 \pm 17$ & $78 \pm 17$ & $\mathrm{NS}$ \\
szívciklus) & & & \\
$\begin{array}{l}\text { BRS } \\
\text { ciky-incidencia } / \text { csúcs/100 }\end{array}$ & $-2,2 \pm 0,9$ & $-1,5 \pm 0,4$ & $\mathrm{NS}$ \\
\hline
\end{tabular}

$\mathrm{BMI}=$ testtömegindex $; \mathrm{BRS}=$ baroreflex-érzékenység; $\mathrm{BRS}_{\mathrm{SY} \text {-incidencia }}=$ csúcsincidencián alapuló szimpatikus BRS; EF = ejekciós frakció; NS = nem szignifikáns; NT-proBNP = N-terminális pro-B-típusú natriureticus peptid; RR-átlag = az EKG-regisztrátum RR-intervallum-hosszúságainak átlaga; RMSSD = egymást követő RR-ciklushossz-különbségek négyzetei átlagának négyzetgyöke; RRSD = RR-intervallumok standard deviációja inkben és kontrollcsoportunkban is szerepelt a kizáró okok közt az extrasystolia (túl rövid ES-mentes szakasz), de az esetek többségében a nagyon beszúkült RR-intervallum-válasz miatt hiányzott a szekvenciákon alapuló baroreflexindex. Az alfa-index ezzel szemben betegeink 69\%-ában értékelhető volt. Vizsgálatunk alapján azok a betegek, akiknél nem volt egyik módszerrel sem kifejezhetó a cardiovagalis BRS, tendenciaszerúen idősebbek voltak, és kisebb ejekciós frakcióval rendelkeztek. Szignifikánsan magasabb volt az NT-proBNP-szintjük, rövidebb volt az átlagos RR-intervallumuk, és beszúkültek a pulzusvariabilitási értékeik (3. táblázat). Bár ebben az alcsoportban szignifikánsan magasabb volt a percenkénti szimpatikus csúcsok száma is, ez a magasabb pulzusszámmal függött össze, és normalizálva (csúcsincidenciaként kifejezve) a különbség eltűnt. Összességében megerősíthetjük a korábbi feltételezést, hogy az indexek hiánya egy súlyosabb betegcsoportot jelöl ki [18, 19].

A cardiovagalis paraméterektől eltérően vizsgálatunkban a szimpatikuscsúcs-frekvencia és -incidencia, továbbá a $\mathrm{BRS}_{\text {SY-incidencia }}$ egyértelmúen elkülönítette a betegeket és az egészséges alanyokat. Megfigyelésünk egybevág a korábbi adatokkal $[21,22,24,25]$.

Fiatalokban vizsgálva a $\mathrm{BRS}_{\mathrm{SY} \text {-incidencia meghatároz- }}$ hatósági aránya több tanulmány szerint magas [8-10]. Hinojosa-Laborde és mtsai egészséges felnőtt alanyok 79\%-ában találták meghatározhatónak a $\mathrm{BRS}_{\mathrm{SY} \text {-incidencia }} \mathrm{t}$ [28]. Jelen vizsgálatunkban a középkorú kontrollalanyoknál ehhez nagyon hasonló, $82 \%$ volt az index meghatározhatósága. A BRS $\mathrm{BY}_{\mathrm{S} \text {-incidencia }}$ meghatározhatóságáról szívelégtelenségben szenvedők körében új, korábban még nem publikált észrevételt tettünk. A betegeknek csak 58\%-ában találtunk elfogadható korrelációs értéket, s ez nyilvánvalóan összefüggött a magas, esetenként 100\%-ot közelítő „burst” incidenciával (2. ábra). Feltehetően itt is súlyosabb betegekról van szó, a magasabb NT-proBNP-szint is ezt erősíti meg.

Vizsgálatunk lehetséges korlátja, hogy a vérnyomáskilengéseknek csak egy szúkebb - a spontán ingadozások révén követhető - mezsgyéjét írja le. A vasoactiv gyógyszereken alapuló tesztek ennél szélesebb sávban jellemezhetik az összefüggéseket, s több az értékelhető regisztrátum. A cardiovagalis paraméterek tekintetében további limitációt jelenthet, hogy ebben a vizsgálatban spontán légzés során készült felvételeket analizáltunk, s szívelégtelenségben gyakori a periodikus légzés, közvetlen autonóm idegrendszeri hatásain túl magát az értékelést (elsősorban a spektrális adatokét) is zavarhatja [29].

\section{Következtetés}

Összességében megállapítható, hogy az RR-intervallum és a systolés nyomás változásain alapuló, noninvazív úton nyert cardiovagalis baroreflexindexek nem alkalmasak a betegek és az egészséges önkéntesek elkülönítésére, de a betegek között e paraméterek hiánya is informatív, egy súlyosabb állapotú alcsoportot jelöl ki. A minimálisan in- 
vazív úton mért szimpatikus paraméterek szignifikáns módon különböznek a betegekben és az egészséges önkéntesekben. A szimpatikus-BRS-index meghatározhatatlansága az extrém magas szimpatikuscsúcs-incidencia következménye, s ugyancsak egy súlyosabb állapotú alcsoportot jelez. Azt, hogy hosszabb távon ez milyen kockázattal társul, folyamatban lévő utánkövetéses vizsgálatunk mondhatja meg.

Anyagi támogatás: A tanulmány alapjául szolgáló kutatást az Innovációs és Technológiai Minisztérium által meghirdetett Felsőoktatási Intézményi Kiválósági Program NKFIH-1150-6/2019. számon támogatta, a Debreceni Egyetem Terápiás célú fejlesztések tématerületi programja keretében. A publikáció elkészítését a GINOP-2.3.2-15-2016-00043. számú, „Szív- és érkutatási kiválóságközpont (IRONHEART)" címú projekt támogatta. A projekt az Európai Unió támogatásával, az Európai Regionális Fejlesztési Alap társfinanszírozásával valósult meg.

Szerzői munkamegosztás: U. R.: Az anyag kidolgozása, a kutatás alapját képező vizsgálatok elvégzése, a kézirat szövegezése. F. I. N., P. T. B., Boczán J.: A kutatás alapját képező cardiovascularis autonóm idegrendszeri vizsgálatok kivitelezése. Barta J.: A kutatás alapját képező cardiovascularis autonóm idegrendszeri vizsgálatok megszervezése, alanyok toborzása, a kézirat szövegezése. É. I.: A kézirat véleményezése, szakirodalmi másodelemzése. Cs. Z.: A kutatás alapját képező cardiovascularis autonóm idegrendszeri vizsgálatok megszervezése, az anyag kidolgozása, szakirodalmi másodelemzés, a kézirat szövegezése, a végleges kézirat szakmai véleményezése. R. L.: A kézirat szövegezése, szerkesztése. A cikk végleges változatát valamennyi szerző elolvasta és jóváhagyta.

Érdekeltségek: A szerzőknek nincsenek érdekeltségeik.

\section{Irodalom}

[1] Rudas L, Crossman AA, Morillo CA, et al. Human sympathetic and vagal baroreflex responses to sequential nitroprusside and phenylephrine. Am J Physiol. 1999; 276: H1691-H1698.

[2] Parati G, Frattola A, Di Rienzo M, et al. Effects of aging on 24-h dynamic baroreceptor control of heart rate in ambulant subjects. Am J Physiol. 1995; 268: H1606-H1612.

[3] Hughson RL, Quintin L, Annat G, et al. Spontaneous baroreflex by sequence and power spectral methods in humans. Clin Physiol. 1993; 13: 663-676.

[4] Zöllei É, Gingl Z, Kardos A, et al. Comparison between different non-invasive indices of baroreflex gain. [A baroreflexek neminvazív jellemzőinek összehasonlító vizsgálata.] Cardiol Hung. 1996; 28: 269-272. [Hungarian]

[5] Laude D, Elghozi JL, Girard A, et al. Comparison of various techniques used to estimate spontaneous baroreflex sensitivity (the EuroBaVar study). Am J Physiol Regul Integr Comp Physiol. 2004, 286: R226-R231.

[6] Sundlöf G, Wallin BG. Human muscle nerve sympathetic activity at rest. Relationship to blood pressure and age. J Physiol. 1978; 274: 621-637.
[7] Kienbaum P, Karlsson T, Sverrisdottir YB, et al. Two sites for modulation of human sympathetic activity by arterial baroreceptors? J Physiol. 2001; 531: 861-869.

[8] Hart EC, Joyner MJ, Wallin BG, et al. Baroreflex control of muscle sympathetic nerve activity: a nonpharmacological measure of baroreflex sensitivity. Am J Physiol Heart Circ Physiol. 2010; 298: H816-H822.

[9] Taylor CE, Witter T, El Sayed K, et al. Relationship between spontaneous sympathetic baroreflex sensitivity and cardiac baroreflex sensitivity in healthy young individuals. Physiol Rep. 2015; 3: el2536.

[10] Hissen SL, El Sayed K, Macefield VG, et al. The stability and repeatability of spontaneous sympathetic baroreflex sensitivity in healthy young individuals. Front Neurosci. 2018; 12: 403.

[11] Lambert EA, Thompson J, Schlaich M, et al. Sympathetic and cardiac baroreflex function in panic disorder. J Hypertens. 2002; 20: 2445-2451.

[12] Keller DM, Cui J, Davis SL, et al. Heat stress enhances arterial baroreflex control of muscle sympathetic nerve activity via increased sensitivity of burst gating, not burst area in humans. J Physiol. 2006; 573: 445-451.

[13] Carter JR, Durocher JJ, Larson RA, et al. Sympathetic neural responses to 24-hour sleep deprivation in humans: sex differences. Am J Physiol Heart Circ Physiol. 2012; 302: H1991H1997.

[14] Ponikowski P, Voors AA, Anker SD, et al. 2016 ESC guidelines for the diagnosis and treatment of acute and chronic heart failure: the Task Force for the diagnosis and treatment of acute and chronic heart failure of the European Society of Cardiology (ESC). Developed with the special contribution of the Heart Failure Association (HFA) of the ESC. Eur Heart J. 2016; 37: 2129-2200.

[15] Eckberg DL, Drabinsky M, Braunwald E. Defective cardiac parasympathetic control in patients with heart disease. $\mathrm{N}$ Engl J Med. 1971; 285: 877-883.

[16] La Rovere MT, Specchia G, Mortara A, et al. Baroreflex sensitivity, clinical correlates, and cardiovascular mortality among patients with a first myocardial infarction. A prospective study. Circulation 1988; 78: 816-824.

[17] Mortara A, La Rovere MT, Pinna GD, et al. Arterial baroreflex modulation of heart rate in chronic heart failure. Clinical and hemodynamic correlates and prognostic implications. Circulation 1997; 96: 3450-3458.

[18] Pinna GD, Maestri R, Capomolla S, et al. Applicability and clinical relevance of the transfer function method in the assessment of baroreflex sensitivity in heart failure patients. J Am Coll Cardiol. 2005; 46: 1314-1321.

[19] La Rovere MT, Maestri R, Robbi E, et al. Comparison of the prognostic values of invasive and noninvasive assessment of baroreflex sensitivity in heart failure. J Hypertens. 2011; 29: 15461552 .

[20] Cohn JN, Levine TB, Olivari MT, et al. Plasma norepinephrine as a guide to prognosis in patients with chronic congestive heart failure. N Engl J Med. 1984; 311: 819-823.

[21] Leimbach WN Jr, Wallin BG, Victor RG, et al. Direct evidence from intraneural recordings for increased central sympathetic outflow in patients with heart failure. Circulation 1986; 73: 913-919.

[22] Floras JS. Sympathetic nervous system activation in human heart failure: clinical implications of an updated model. J Am Coll Cardiol. 2009; 54: 375-385.

[23] Barretto AC, Santos AC, Munhoz R, et al. Increased muscle sympathetic nerve activity predicts mortality in heart failure patients. Int J Cardiol. 2009; 135: 302-307.

[24] Ferguson DS, Berg WJ, Roach PJ, et al. Effects of heart failure on baroreflex control of sympathetic neural activity. Am J Cardiol. 1992; 69: 523-531. 
[25] Grassi G, Seravalle G, Cattaneo BM, et al. Sympathetic activation and loss of reflex sympathetic control in mild congestive heart failure. Circulation 1995; 92: 3206-3211.

[26] Heart rate variability: standards of measurement, physiological interpretation and clinical use. Task Force of the European Society of Cardiology and the North American Society of Pacing and Electrophysiology. Circulation 1996; 93: 1043-1065.

[27] Kardos A, Watterich G, de Menezes R, et al. Determinants of spontaneous baroreflex sensitivity in a healthy working population. Hypertension 2001; 37: 911-916.

[28] Hinojosa-Laborde C, Ryan KL, Rickards CA, et al. Resting sympathetic baroreflex sensitivity is subjects with low and high toler- ance to central hypovolemia induced by lower body negative pressure. Front Physiol. 2014; 5: 241.

[29] Mortara A, Sleight P, Pinna GD, et al. Abnormal awake respiratory patterns are common in chronic heart failure and may prevent evaluation of autonomic tone by measures of heart rate variability. Circulation 1997; 96: 246-252.

(Rudas László dr., Szeged, Semmelweis u. 6., 6725 e-mail: rudas.laszlo@med.u-szeged.hu) 